\title{
Witchcraft and its impact on black African Christians: A lacuna in the ministry of the Hervormde Kerk in Suidelike Afrika ${ }^{1}$
}

\author{
Matsobane J Manala ${ }^{2}$ \\ Department of Practical Theology \\ University of South Africa
}

\begin{abstract}
Witchcraft is presented as a threat to the life and well-being of the people of Africa, their embracement of Christianity notwithstanding. This article seeks to highlight the negative impact of witchcraft beliefs and experiences among many African people, including Christians and the educated, that is, "educated" in the western sense. The article identifies a lacuna in the Hervormde Kerk in Suidelike Afrika's ministry to the sick and to those who find themselves engulfed by misfortune in one form or another and believed to have been caused by witchcraft. The article points to the need for a ministry that will be relevant and meaningful in addressing the illnesses and misfortunes of black African Christians.
\end{abstract}

\section{INTRODUCTION}

Witchcraft, coupled with the negative impact it has on the lives of Africans, including African Christians, is quite horrendous. Christianity in Africa has to take seriously the problem of disorientation or disequilibria caused by the belief in witchcraft among the people of Africa, even those who have embraced the Christian faith. In this article, I initially examine the definitions of

\footnotetext{
1 "Hervormde Kerk in Suidelike Afrika", (acronym HKSA), is translated as "Reformed Church in Southern Africa," refers to the Reformed church that was established in 1923 in the former Natal Province of South Africa. The church was established and expanded under the guardianship and financial support of the "Nederduitsch Hervormde Kerk van Afrika" which is translated as "Dutch Reformed Church of Africa".

${ }^{2}$ The article has been processed from a paper delivered at part of the Continued Theological Training for Ministers of the HKSA, 9 July 2003 at Dududu in Kwa Zulu/Natal, organised by the Hervormde Teologiese Opleiding (Hammanskraal).
} 
the concept witchcraft and related concepts, namely witch, sorcerer, witch doctor, diviner, and herbalist. The definitions are meant to shed some light on the phenomenon of witchcraft. Secondly, the relationship between witchcraft and disease in black communities is examined to establish the extent of the need for church to reflect upon the matter and to institute action. Thirdly, I highlight the negative impact witchcraft has on the lives of black African people, including Christians, both in rural and urban areas.

Fourthly, I present Reformed theological principles upon which the ministry of the Hervormde Church family is founded and critically interrogate their efficiency, effectiveness and meaningfulness for black African Christians who are sick and dying as a result of what they believe to be witchcraft-related attacks. Fifthly, I point to the void that exists in the ministry of the Hervormde Kerk in Suidelike Afrika and highlight the need for a ministry design that takes the African world view seriously.

\section{DEFINITIONS OF IMPORTANT CONCEPTS}

In order for some light to be shed on the concept of witchcraft, it is important to search for the meaning of the phenomenon. The following definitions of the concept witchcraft and related issues may help in shedding some light on the phenomenon of witchcraft and its impact on the life of black Africans.

Concepts that have to be considered for definition in conjunction with witchcraft are witch, sorcerer/sorceress, witch doctor, diviner and herbalist.

\subsection{Definition of witchcraft}

Wehmeier and Ashby (2000:1371) define witchcraft as "the use of magic powers, especially evil ones." The concept, witchcraft therefore refers to the use, by some people of evil magic powers to harm or cause misfortune to others. Witchcraft is therefore regarded as "... the supposed power of a person to harm others by occult or supernatural means, without necessarily being aware of it ... ( $\mathrm{T}$ )he essence of witchcraft and sorcery is the causing of harm to persons or property by invisible means" (Hayes 1995:339-340). Shorter (1985:95) defines witchcraft as "a kind of penumbra of human wickedness, an inborn preternatural power to harm and kill, enjoyed for its own sake."

Witchcraft thus is an anomaly that needs a sound Christian response in respect of both the practitioners and victims thereof. In a way, both are victims in that the practitioner, in some instances finds him- or herself invaded and possessed by this evil power, not by choice but either by inheritance or as a supernaturally inborn force. Those who are bewitched or believe themselves to be bewitched experience tremendous pressure. I prefer to refer to this 
group as direct victims because they are targets of evil spells and curses that are aimed at harming them for some reason or the other. The former group will fit the description indirect victims as they are in a certain sense the carriers of evil powers and executors of evil acts. These people are said not to derive pleasure in executing acts of witchcraft, as it is forced upon them through powers beyond their control. A person, especially a woman who practises witchcraft, is called a witch.

\subsection{Definition of a witch}

Wehmeier and Ashby (2000:1371) define a witch as "a woman who is believed to have magic powers, especially to do evil things. In stories, she usually wears a black pointed hat and flies on a broomstick." The description of a witch as wearing a black pointed hat and as flying on a broomstick depicts a witch as it is conceived by a European mind. According to the African understanding a witch may even go without clothing a scenario that specifically applies to night witches. The understanding in Africa is that a witch is out to cause harm to others. Parrinder (1971:61) makes the following statement about a witch: "The witch is generally thought to fly at night from her sleeping body and feed on the soul of her victim who thereupon sickens and dies." This amounts to the most horrendous act of destruction of another human being - feeding on his or her soul. Kritzinger (2004:180) also describes the African witch in almost similar terms:

In Africa, witches are always viewed as evil, and are not always female. In many African countries, it is believed that witchcraft runs in the family and that one is born a witch. Witches are believed to have a natural inclination to carry out evil, making people ill and even causing death.

A witch is traditionally thought of as a person who can hurt others by virtue of an inherent quality. A witch performs no rite, utters no spells and possesses no medicine. An act of witchcraft is a psychic act, which sometimes is involuntary (Za'li 1999:4). This view is also supported by Hayes (1995:339), when he says: "The witch does not choose to be a witch, and the supposed harm does not necessarily arise from malice or intent." Kgatla (2000:244) points in the same direction when he states: "The witch is thus held to be a person in whom a distinctive illness dwells, whereby in mysterious ways he/she harms his/her fellows." If it is true that a witch suffers from an involuntary compulsive disorder that forces her to do evil deeds to her fellows, then she is indeed also truly a victim. 
According to oral and literary evidence, there are two categories of witches, namely day witches and night witches. A "day witch" is any ordinary individual who acquires the ability to use evil magic powers or spells from some expert, with which ability he/she tries to kill his/her identified prey, with or without cause (Kgatla 2000:149). Day witchcraft can therefore be acquired by buying it from someone who practises witchcraft (Nyirongo 1997:184). Day witches therefore learn the practice of witchcraft. Hayes' (1995:340) description of sorcery fits Kgatla's (2000:149) description of "day witchcraft": "Sorcery may be learned, whereas witchcraft is intrinsic." According to Kgatla (2000:149), "day witches" are so resolute to commit acts of witchcraft that they can only be deterred or stopped by being put to death.

A "night witch" on the other hand is one who is able to perform his or her evil activities without the aid of magical potions. They are said to be mostly women who walk naked at night, even during the coldest of nights. Night witches are feared, especially because they can enter closed huts, work during the night and make use of familiars such as hyenas, dogs, cats, owls, snakes, lightening, birds and so forth, to carry out their evil deeds (Kgatla 2000:149-150). Kritzinger (2004:180) alludes to the fact that in Africa, witches are believed to be using hyenas as means of transport. They are also blamed for causing certain serious diseases, such as tuberculosis, paralytic stroke, and so forth and are able to cause death, pain and misery. These, they cause by inter alia pointing a finger at their victims, through food poisoning,by mixing some magical potions with the soil on which their victims footprints are made to inflict pain on them and by lightning (Kgatla 2000:150). Night witches are also believed to be able to cause infertility and to turn people into zombies and so forth (Kgatla 2000:154). Wehmeier and Ashby (2000:1390) describe a zombie as perceived in Africa, as "a dead body that has been made alive again by magic." The death of such a person is usually believed to be caused deliberately by evil magical means for a specific purpose. Kgatla (2000:154) therefore describes a zombie as "a human being who has been killed and his/her soul turned into a slave for the witch." Some of these people are said to be seen in trains in industrial areas where they are said to work for the sustenance and livelihood of their witch master. Therefore, night witches are said to be extremely fearsome and dangerous to the community. Kgatla (2000:245) lists the following basic beliefs regarding witches:

- $\quad$ Firstly, a certain category of persons, especially women, has recognisable and particular signs that single them out to be identified as witches. These people may bear physical stigma, such as red eyes, have a reserved personality, and be stingy or quarrelsome. 
- $\quad$ Secondly, certain misfortunes are ascribed to witches. These include natural calamities such as death, illness, drought or natural disaster. However, the context of the misfortune is always apparent.

- $\quad$ Thirdly, witches turn against their own people and kinsmen; they do not harm strangers or people from far away.

- Fourthly, they are driven by envy, malice or jealousy of individuals, rather than being in pursuit of material gain as such.

- $\quad$ Fifthly, witches reverse all normal/acceptable standards. For instance, they eat their own children, dig up corpses, go naked at night, meet at particular spots to plan their evil deeds, and enjoy practising their craft.

Witches are not only feared, but also hated because they make life unbearably difficult for individuals, families, communities and societies. Maimela (1985:68) aptly articulates society's terror of witchcraft as follows:

It is against this background of appalling terror and deep revulsion against witchcraft that the traditional African is apt to call every premeditated enmity, hatred, evil speaking or any act directed towards the destruction of the life of others "witchcraft" and therefore evil and sinful in the highest degree in God's sight.

Ramashapa (1996:355) also points to this hatred of and cruelty against witches: "People who practise 'boloi' (witchcraft) are feared and hated by the community. If they are found in action they are either punished by gruesome death or they are forced to leave that community."

It is unfortunate that there are apparent contradictions contained in definitions and descriptions of the phenomenon, which impede the certainty in this regard. Kgatla (2000:149) for example points out that day witches are so resolute in their resolve to kill, and therefore become such a big threat to the community that the only effective way to deal with them is by killing them. However, the same does not apply tonight witches. Kgatla (2000:151), while ascribing appalling acts to night witches, only refers to how the community fears them, and does not mention the community's hatred towards them and the punitive action taken against them.

Although there is no such thing as a friendly and soft witch, a night witch is assumed to be the most feared and dangerous to the community. The danger posed by a day witch seems to be more avoidable than that posed by a night witch. A day witch largely depends on medicines to kill, rather than on 
supernatural powers with an ability to undermine all human precautionary measures, as night witches use. In addition, night witches also have access to magical potions, for example food poison (Kgatla 2000:152), even though the description of night witches here above points to the contrary (Kgatla 2000:149). The words of Boakye-Sarpong and Osei-Hwedie, cited by Nyirongo (1997:183) may explain the seeming contradictions: "Witchcraft may be distinguished from sorcery even though the acts of witches sometimes merge with those of sorcerers. Whereas the power of a sorcerer is embodied in the medicine he or she uses, the power of witchcraft, on the other hand, is a mystical and innate one even though witches also use medicine when the need arises." It therefore appears to be rather difficult to make clear distinctions between the various categories describing the phenomenon of witchcraft.

The description of night witches' acts of witchery as unintentional is problematic especially in view of acts of turning people into zombies and making them work as their slaves. It would appear as if the "killing" and the act of turning the person into a zombie have a clear economic purpose. This is confirmed by Nyirongo (1997:184) who in his description of the fourth way of acquiring witchcraft, mentions "... to buy it from a 'dealer'- a sorcerer who practises witchcraft as a commercial undertaking." It is therefore, a premeditated and thus an intentional act. Because of these contradictions, it is not easy to successfully use fixed postulates to describe and categorise the phenomenon of witchcraft. For example the terms describing different categories are sometimes used interchangeably. The word "witch" is at times replaced with "sorcerer" (cf Ramashapa 1996:358). Hayes (1995:340), alluding to the same problem, says "... the terms have been used interchangeably" (Parrinder1958:18). In newspaper reports of recent witch hunts in South Africa, for example, the terms "witch", "sorcerer" and "wizard" are used to translate the Zulu umthakathi or Sotho moloi.

\subsection{Definition of a sorcerer/sorceress}

Wehmeier and Ashby (2000:1134) define a sorcerer briefly as: "a man with magic powers, who is helped by evil spirits" and a sorceress as "a woman, fitting the same description". The art in which the sorcerer and the sorceress are involved, is called sorcery and refers to: "magic that uses evil spirits" (Wehmeier \& Ashby 2000:1134).

A sorcerer or sorceress uses evil spirits to cause ailments or misfortune to those targeted for attack. Za'li (1999:5) describes a sorcerer thus: "A sorcerer is a person who brings misfortune to others by purposeful use of magic rites. Sometimes called day witches (as opposed to night witches), 
sorcerers intentionally harm others by the use of spells, charms, or poison and are universally held in a negative light." Here again Za'li uses the term "sorcerer" to refer to what Kgatla (2000:149) calls a "day witch".

\subsection{Definition of a witch doctor}

Wehmeier and Ashby (2000:1371) define "witch doctor" as one "who is believed to have special magic powers that can be used to heal people." The above concept of an African witch doctor compares well with the American Native healer, known as the medicine man. Za'li (1995:5) states: "A witch doctor is the equivalent of 'spiritual police'. They use spells, spirits, or 'second vision' to discern who the witch is, and expose them to the community. As a result, they are almost universally held in high regard as friends of the community."

The term "witch doctor," taken on face value may be misleading, because it limits the task and responsibility of the traditional medicine man (witch doctor) to anti-witchcraft activities or even implicates him/her in the practice of witchcraft (Shorter 1985:8). Shorter gives a broader description of the task, activities, skills and competencies of an African traditional medicine man/woman (witch doctor) as follows:

The term is used to refer to traditional diviner-doctors in pre-literate societies, particularly in Africa. Divination is a form of revelation. It goes beyond mere diagnosis, the examination of the patient and the knowledge of natural cures and remedies to include the analysis of dreams, the restoration of mental hygienic balance and the dynamics of human and supra-human relationships. The healing performed by a traditional diviner-doctor is carried out at various levels and by various means. There may be a greater or lesser proportion of treatment of physical ailments, using herbal remedies. There may be a care and respect for the natural environment and a preoccupation with social reconciliation as a prerequisite for healing. Attention may be paid to the effects of enmity, to cursing, to witchcraft and sorcery, as well as to the intervention of ancestral spirits and non-human or supra-human agencies.

(Shorter 1985:8)

The so-called witch doctor is therefore engaged and involved in the broad task of resolving health/illness issues, as well as in predicting the future in order to bring transformation that will improve the conditions of individuals within black African communities. The traditional healer (witch doctor) also has as task and responsibility the healing of relationships, that is between fellow humans, 
people and their ancestors, people and nature spirits, and between people and the environment. The name "witch doctor" does not therefore convey the full spectrum of the role and function of the traditional medicine man/womandiviner.

\subsection{Definition of a diviner}

A diviner is any individual who is appointed by his or her ancestor who was a diviner him- or herself, to become a traditional community health worker and protector against evil powers. Such an appointed person has to undergo training following confirmation of his or her calling by the community (Berinyuu 1988:39). The training covers issues such as technical and "oral knowledge", knowledge transmitted by word of mouth and the ability to submit to the spirit of the ancestor for direction, as well as knowledge about other necessary divination techniques (Berinyuu 1988:39). Differently put, the training covers knowledge of herbs, bone throwing methods, interpretation of bones, communication skills, listening skills and obedience to the ancestor's instructions and so forth.

The words diviner and witch doctor seem to refer to the same person. The diviner, however, has the additional responsibility to protect communities as well. Za'li (1995:5) for example, says: "A diviner also provides protection from evil powers, including witches, sorcerers, and spirits." The diviner further has the task of disclosing the causes of misfortune and death. As was indicated in the previous section, Shorter (1985:8) also alludes to this aspect.

\subsection{Definition of a herbalist}

A herbalist refers to one who grows, mixes and sells various herbs for medicinal purposes. Mixtures are available for almost anything, from medical problems to love potions. Herbalists, together with witch doctors and diviners, also provide protection in the form of personal charms against evil. The charms of witch doctors are generally considered more powerful than those of herbalists (Za'li 1999:5).

All of the above concepts (i.e. herbalists, diviners and witch doctors) represent attempts of describing life in Africa as an involvement in one way or another with witchcraft, especially the combating thereof

\section{THE RELATIONSHIP BETWEEN WITCHCRAFT AND SICKNESS/ILLNESS}

It cannot be disputed that to the African mind, sickness and misfortune are closely linked to witchcraft, insofar as witchcraft is regarded as the primary cause thereof. Mbiti (1970:68) writes: "The Nyakyusa believe that God has the 
power to drive away the witches who in African societies, are thought to be the main cause of sickness and misfortune." While Africans basically categorise the causes of illness into three categories, namely: ancestors, witches/sorcerers and nature, it is sicknesses caused by witches and sorcerers that are said to be fatal (Moila 2002:23).

Unfortunately, illnesses caused by witchcraft outnumber and occur more frequently than those resulting from the other two causal categories. Van Dyk (2001:61), citing Hammond-Tooke, points to the preponderance of witchcraft as the perceived cause of illnesses and misfortunes in both rural and urban areas. Statistics cited by Van Dyk (2001:61) indicate the following: in rural areas traditional healers indicate that $72 \%$ of cases can be ascribed to witches or sorcerers; $8 \%$ to ancestors and $17 \%$ to non-mystical factors such as drunkenness and accidents. In an urban area the figures are slightly different, though essentially still indicating a strong causal link between witchcraft and illness: $45 \%$ of illnesses can be attributed to witchcraft or sorcery; $7 \%$ to ancestors and $48 \%$ to non-mystical factors. Even though witchcraft and sorcery are rated lower than non-mystical factors as the cause of sickness and misfortune in an urban area, at 45\%, the figures remain relatively high.

Despite current levels of Western education and technological advances among black Africans, the belief in witchcraft persists. Stebbing (1985:172) highlights the fact that the Shona people live amid three cultures, three worldviews, namely the traditional, the Western and the purely Christian one. However, the traditional culture and worldview seem to dominate the African view in illness/health matters. The traditional culture and worldview maintain that sickness is caused by witchcraft. There is no illness of which witchcraft is not the cause. According to Stebbing (1985:172), this traditional view is "said to be in their (Shona people's) blood." It means that the traditional African mind explains the illness/health matters primarily from the African worldview. Sow, as cited by Van Dyk (2001:61), confirms the position that most illnesses and other disturbances to human peace are caused by witchcraft: "Knowledge about their meso-cosmos is especially important for understanding the behaviour of Africans because nearly all forms of illness, disease, conflict, suffering, misfortunes, accidents and death are ascribed to this level ... The meso-level is described as the intermediate universe, that is the universe between the macro-cosmos and the micro-cosmos, and is inhabited by genies, evil spirits, witches and sorcerers." Moila (2002:23), dealing with sources of sickness among the Zulus, says: "Angered fellow humans are the sources of the sicknesses which are unto death." These 
sicknesses are commonly called "ukufa okulethwe umthakathi" (which means the sickness that is brought about or caused by the witch) (Moila 2002:23).

One whose life is invaded by witches is rendered totally hopeless and helpless. The desire of such a person to live and prospects of prosperity are shattered beyond restoration. Shorter (1985:34), after referring to the noble suffering that serves the society as bearable in Africa, continues to write about the nature of suspected "witchcraft illnesses":

It is the suffering that saps life that is intolerable, the suffering that serves no cause. Such suffering reduces the will to live. People even will themselves to die in such circumstances. Missionaries and doctors working among the traditional societies of the Third World frequently report cases of "witchcraft illness," people dying with no apparent scientific medical cause, people who have just decided to die.

(Shorter 1985:34)

From the above there can be no doubt that witchcraft is often linked to sickness and misfortunes in the African's world of thought. When ill health, misfortune, accident or death occur, traditional Africans will immediately probe witchcraft as the likely cause.

\section{THE IMPACT OF WITCHCRAFT ON THE LIVES OF BLACK AFRICAN CHRISTIANS AND THE AFRICAN CHURCH}

Witchcraft victimises black Africans, including Christians and has a negative influence on their lives. According to Maimela (1985:68) witchcraft is classified among Sawyer's four types of sins that call for salvation. Maimela (1985:68) explains the victimisation as follows:

... the traditional African is a victim of anxieties that are born out of evil spirits and malicious persons, especially witches and sorcerers. Accordingly, most Africans express an intense revulsion against all forms of diabolical evil embodied in witchcraft, because not only does it prostitute the laws of nature by a deliberate manipulation of the vital forces for destructive purposes, but also poisons all human relationships, thereby threatening the corporate nature of society.

Witchcraft raises intense fear and revulsion because it destroys human life, human community and shatters dreams and visions of individuals and societies. People need salvation from this evil. Maimela (1985:68) 
emphasises both the malevolent nature of witchcraft and humanity's dire need for salvation when he says: "Evil spirits and witchcraft are therefore the greatest injustice imaginable towards a community - a sin against which traditional Africans spend their greatest energies, trying to procure relief or salvation from ...." According to the African world view, salvation does not in particular refer to the eschatological life of glory but to a life of happiness, good health and prosperity, here and now. Ramashapa (1996:358) declares: "For them salvation is to "[go] gata tala e bola" - total peace, good health and prosperity. Salvation for them is good life."

In view of the aforesaid, witchcraft has a very negative impact on members of various black communities, including Christians. This phenomenon is regarded, especially by the Northern Basotho people as an existing permanent life-threatening reality and practice (Ramashapa 1996:358). It is a life-threatening evil, not only to those who fear for their lives because of bewitchment, but also those who are said to practise it. Haule (1969:146) cites Father Albert's statement on the negative impact the belief in witchcraft has on people: "It depresses the soul with its eternal fear, and destroys all too often the body; it leads to suspicion and hatred, nay, to mutilation and murder ...." The horrendous acts of witch hunts and witch murders in many rural parts of South Africa, especially in the Limpopo Province are known to many people (Kgatla 2000:6). Aylward Shorter (1985:97) describes the situation especially as it relates to individuals suspected of witchcraft practices, quite aptly: "To accuse people of witchcraft practices is to destroy their social personality, if not to condemn them to a more merciful (sic) death." Such suspicions are indeed condemnatory and inflict irreversible damage, both physically and socially on the one who is suspected of witchcraft activities. Suspicions of witchcraft can stigmatise the entire family and its progeny for generations.

Beliefs in witchcraft have serious negative economic implications as well. Those who are afraid of being bewitched are forced to spend a fortune to acquire the strongest protective muti (medicine). One form of protecting individuals and families is to strengthen one's homestead (go tiisa motse) which entails employing a traditional doctor to put medicine around the homestead (Ramashapa 1996:358). For this medicine to retain its effectiveness, it has to be renewed each year. People are charged many head of cattle in exchange for these services. Ejizu (2002:12) makes the following statement with regard to the measures people take to protect themselves against the actions of witches and wizards: "People protect themselves against their nefarious activities through different kinds of ritual practices including offering ritual sacrifice, making and wearing of charms and amulets." 
So dangerous for human life and survival are witches that people who find themselves in the grip of bewitchment have to seek help, not only from humans but also from divine and spiritual powers. Should they forget to renew the protective measures, they open their homestead to onslaughts of witches. In traditional Africa an unprotected homestead is referred to as the playing ground for witches and its occupants are in danger of becoming easy targets of witches.

The impact witchcraft has on the way in which the church fulfils the missio Dei is devastating. The growth of the church is greatly impeded. Members leave in their thousands those churches that do not take seriously and address the threat posed by witchcraft. Ramashapa's (1996:358) assessment of the situation is rather accurate: "The movement of church members from churches that do not clearly practise faith healing to those which practise it is a sign of fear of boloi and other destructive powers." Of course, the exodus of members from many mainline churches to the African Initiated Churches and charismatic movements is not only well known, but is also cause for grave concern for mainline churches wherever they operate.

It is obvious that the Christian church has to do something about this state of affairs. The question is how can the church counteract witchcraft in order to facilitate appropriation of the Christian faith and the promise of abundant life. Unfortunately some people do not seem to realise the need for the church to find appropriate ways of reclaiming the situation. Many ministers are assumed to maintain the position that the church should continue to preach the pure gospel of Jesus Christ. The importance and need for the church to preach the gospel of Jesus Christ in as pure a way as possible, cannot be refuted and is indeed the church's central task and responsibility. The question, however, does not only concern the "what?" of preaching but also the "how" of proclaiming the gospel. Does the way in which we serve African Christians in the context of their existential problems, which among others include witchcraft, really suit their conceptual framework? The way in which the gospel is proclaimed should be both transformative and liberative and the church in Africa should find ways of providing a transformative and liberative service to its members.

The question, however, is whether witchcraft is an existing reality. This issue needs to be investigated in order to discover the truth. The next section deals with the existence or non-existence of witchcraft.

\section{DOES WITCHCRAFT REALLY EXIST?}

This is a difficult question to answer. It can indeed only be answered from the perspective of a particular worldview. We have two frames of reference from 
which we can attempt to answer the abovementioned question, namely the western worldview and the African worldview.

From the western worldview, which is largely influenced by enlightenment thinking, the answer to the abovementioned question will be an emphatic "no". Gerkin (1997:44) describes the enlightenment as "an age marked by the rise of secularism: the belief that human history as well as contemporary life can be understood without speaking of God or assuming divine activity in human affairs." In terms of this worldview the reality of witchcraft and other supernatural forces will probably be rejected in the same way the existence of demons is rejected as a form of escapism (Van Aarde 1987:13). Stating the objective of his article, Van Aarde (1987:13) says that he wants to indicate firstly, that believing in the devil is a form of escapism. Secondly, he "wants to show that to believe in the devil is in direct contrast with believing against the devil", the latter being the attitude the New Testament demands. At the end of his article, Van Aarde (1987:34) demonstrates the nothingness of evil by using a metaphor of small holes in a Swiss cheese, borrowed from Russel: "Evil exists in the cosmos like holes in a Swiss cheese: the holes are there, but they are there only as non-cheese and have no existence apart from the cheese. As one cannot eat the cheese and discard the holes into a box, one cannot remove good and put evil into another category." This position is undoubtedly insightful and of great value in a western, modern and secular setting.

It is, however, not relevant in an African context at the core of which is the belief in the existence of ravaging spiritual forces which deprive human beings of peace. The question whether witchcraft really does exist, does not belong in an African context. In the minds of many African people there is no doubt as to the reality of witchcraft. Mwalwa (1999:6), dealing with almost a similar question than the one above, states: "I am convinced that witchcraft is NOT imaginary, nor unreal. It is still a strong force in Africa ..." It does not simply exist as nothingness as Van Aarde suggests in the metaphor about the small holes in a Swiss cheese. For many African peoples it is an existential reality. The entire life of African people is said to be an involvement with witchcraft - the prevention but also the practice thereof. According to Stebbing (1985:189), Monica Wilson and Aylward Shorter note in consort, the importance of the witch as an embodiment of evil in the traditional African context. The belief in witchcraft is quite central to the traditional African community. It is among important elements that exercise influence in the traditional religions of the southern and eastern African countries. According to Stebbing (1985:190), Monica Wilson notes four such elements, which are: a cult of shades, belief in God, belief in the power of medicines and fear of 
witchcraft. After a discussion of witchcraft, Ramashapa (1996:358) makes the following statement, using the term "sorcery" for "witchcraft": "Sorcery is regarded by the Northern Basotho as an existing reality." To these people, the fear of boloi or witchcraft is thus very real. In the light of the above insights the service of the Hervormde Kerk in Suidelike Afrika to black African Christians is not relevant because it is founded on a theology influenced by western thought and philosophy. This theology is shaped and governed by the western worldview, which does not relate to, but negates the African worldview.

What follows is a presentation in summary, of the theological principles which form the basis of pastoral care to the sick, as articulated and practised by the Hervormde Church family. I present this theological framework in appreciation of its scientific theological contribution as well as the limitations of that contribution in dealing with the uniquely African context.

\section{REFORMED THEOLOGICAL PRINCIPLES GOVERNING SPECIAL PASTORAL CARE IN THE HKSA}

From what is evident from both the Old and the New Testaments, particularly from Jesus Christ's concern and care for people, especially those in distress, the following theological principles can be listed (Van Biljon 1984:2; Dreyer 1981:23; De Klerk 1978:17; Kramer 1978:22):

The revelation of God in the Holy Scripture is the primary principle that governs the pastoral care as proclamation. The following can be said about pastoral care as proclamation:

- Pastoral care is revelation theology and not an existential theology. Humankind can never serve as source, basis and norm of pastoral care.

- God's acts of redemption are found in the Word which is the essential mode of revelation.

- Pastoral care becomes true proclamation, only when it actualises God's acts of redemption within humankind's wrestling with the truth. Only then, can the encounter between God and humankind, in which God truly addresses humanity, take place.

As a conversational proclamation, pastoral care is a para-liturgical form of service within the ecclesial service structure and has the edification of the body of Christ as goal. Pastoral care therefore ensures that: 
- those who hear the Word of God live in obedience to the Word

- and their witness about Christ will lead them back to the service of worship.

This kerygma includes elements of admonition, rebuke, comforting, training and encouragement. The Spirit employs the biblical kerygma as a means through which the Spirit comforts and instructs the counselee and raises his or her faith.

Special pastoral care is focussed or specialised service to an individual who is in tribulation and if necessary, also to the family that has to endure the pain inherent in that situation. It is proclamation to a person in his or her contextual needs but it does not mean that the special pastoral care seeks in an empirical-critical way, a technique for religious influence of the person in his or her concrete situation but rather a joint search for the truth of God's Word. That is the only way in which the redemptive revelation of God's Word can be actualised in humankind's wrestling with the truth.

It remains the responsibility of the pastor to unconditionally adhere and remain loyal to the Scripture. The pastor should proclaim the Scripture in its full richness as the authority of the Word of God. The Word of God derives this authority from the Holy Spirit. The pastor is in other words the carrier of the kerygmatic message from whence his authority comes. The kerygma therefore becomes the gracious speech to the counselee in his or her greatest crisis, that is the crisis of sin.

Because of the fact that special pastoral care is a person-focussed conversational proclamation, it is necessary that the basic elements of a successful conversation or communication be taken into account. In spite of the fact that special pastoral care adheres to the theological principles, it displays some flexibility with regard to the pastoral conversation, which fits into a different method from that of the pastoral care in general.

Although there is a systematic differentiation between various modes of proclamation, they all run in consort towards one proclamation goal, are interdependent and bear overlapping characteristics.

Where special pastoral care uses the theological-critical method, the norm that it should function as a fully-fledged theological discipline that is completely loyal to the Word of God applies. In this case other theological disciplines interpret the pastoral labour while pastoral care determines the how of the person-focussed conversational proclamation as well as fulfilling a stimulating and a serving function within the entirety of the theological study.

Furthermore, pastoral care utilises knowledge from, and results of nontheological disciplines that are believed to be subservient to theology, without 
falling into subjective, anthropological processes or without becoming a superficial companion of these non-theological disciplines. The axiom that applies in the special pastoral care is that everything ultimately revolves around the revelation of God in Jesus Christ through the work of the Holy Spirit, as attested in the Scripture and understood in the lives of people through the Word and Spirit of God.

From the aforementioned theological principles, Van Biljon (1984:33) concludes that a theologically balanced pastoral care is kerygma, that is communication of the Word that inspires every situation, guiding the counselee to faith in Christ, which in turn leads to a new meaning of life and transformation, to the glory of God and edification of the body of Christ through the work of the Spirit.

The Hervormde Church family's ministry focuses mainly on pastoral care to the sick. It means that the church is content with providing a supplementary service to the work of the medical doctor with prayer and soul care (Jonker 1986:143). This is really not adequate to effectively counter mysterious forces that are inherent in witchcraft beliefs and are so overwhelming to black African Christians.

This deficiency can also be observed in the curriculum of the theological training of the Nederduitsch Hervormde Kerk van Afrika responsible for the training of ministers of the Hervormde Kerk in Suidelike Afrika, the latter which should be equipped to serve black African Christian communities. All the sub-disciplines of Practical Theology, that is, care, homiletics, catechetic, liturgics, ministry to the poor and the sick deal with issues in a manner that, though theologically formative and insightful, does not help ministerial trainees to grasp and effectively practise ministry in the African context. Topics dealt with and literature prescribed, focus on the teaching of theology from the perspective of the western worldview. One reason for this state of affairs is that until very recently the lecturing staff of the Hervormde Teologiese Opleiding (HTO) has been entirely white. The contribution of some recently included black ministers, unfortunately also the products of the western theological discourse, in recognition of the need for an African perspective, is minimal. This does not, however, suggest that there are no genuine attempts by some lecturers of the HTO to include some aspects of the African perspective. While these attempts are laudable, the dominant context is still that which is linked to the western worldview. The following is a list of issues that are dealt with in the training of ministers of the Hervormde Kerk in Suidelike Afrika.

The issues are listed within relevant sub-disciplines of Practical Theology, starting with Pastoral Care and Counselling: 
- In the introduction to Pastoral Care, Gerkin's work is used An introduction to Pastoral Care is used The author is a North American Practical theologian who wishes to see a healthy interaction between the Christian religious contribution and that of the contemporary culture of people.

- $\quad$ Fundamental aspects of Pastoral Care: This section provides different terms and metaphors used to explicate the nature, meaning and function of Pastoral Care as communicative action in the service of the gospel.

- $\quad$ The aim and functions of Pastoral Care. The aim of Pastoral Care is described as healing, sustaining, guiding and reconciling.

- $\quad$ Different levels or forms of Pastoral Care, namely mutual care, pastoral care, pastoral counselling and pastoral therapy.

- $\quad$ The context in which Pastoral Care takes place. This section takes cognisance of different cultural and other situational issues that determine the approach and method of Pastoral Care. The African perspective is considered for pastoral assistance of families.

- $\quad$ The communicative process in Pastoral Care. The section addresses basic principles of the caring dialogue, explains conditions of a therapeutic relationship and describes the six basic attitudes in pastoral dialogue.

- $\quad$ Crisis Counselling. Terms related to crisis counselling are clarified, characteristics of crisis are described. Pastoral Care to the sick, with DJ Louw's work as frame of reference, is offered.

- In all of the above, concern for African issues is but minimal as most of the work in accordance with the western world view.

Family care is also briefly dealt with, with some reference to the African family situation. Three articles by three authors with a particular interest in African issues, namely Daisy Nwachuku's "Family life patterns and Christian Counselling in contemporary Africa", Leslie E Shyllon's "Aspects of Pastoral Counselling in the context of African marriage: Some case presentations", and Emele M Uka's "Broken homes and strategies for renewal" are used as references in this regard. The works of Dreyer and Stone are also prescribed for this module.

Homiletics is another religious communicative action that is studied in Practical Theology at the HTO. In this module, the following topics are treated: 
- The origin of Christian preaching. The origin of Christian preaching is traced in the prophetic books of the Old Testament, for example, Isaiah and Ezekiel and in the New Testament that is, in the Synoptic Gospels, other books and epistles.

- The commission to preach.

- The goal of preaching.

- The content of preaching.

- The preconditions of preaching.

- The process of sermon preparation.

- Delivering the sermon. Jay E Adams' work, Preaching with purpose is the prescribed work for this module.

The module on catechetic instruction has the following topics:

- Biblical instruction in general, dealing with various definitions by different authors, namely, Groome, Van Uchelen, Van der Westhuizen, De Wet, Velthuysen and Beukes.

- Instruction in the Bible.

- The aim of Church instruction.

- Persons and bodies responsible for church instruction.

- The child in the instruction process.

- The instruction material.

- Lesson planning and proposal.

- Instruction in the HKSA.

- Instruction practices.

Liturgics or worship is another area in which knowledge is communicated to ministers of the HKSA to enable them to conduct worship services meaningfully. Different topics are dealt with, namely:

- The service of worship in the HKSA.

- Celebration as communicative act of faith in the Christian service of worship.

- Biblical perspectives.

- Liturgical traditions, in which the Roman Catholic, the Eastern Orthodox, the Lutheran, Reformed, Anglican, Methodist and the charismatic liturgical traditions are considered. However, liturgical traditions of the African Initiated Churches are excluded. 
- The significance of different liturgical traditions for the service of worship in the HKSA.

- General principles in respect of the liturgy for preparing a service of worship.

- Planning a service of worship. In all of this and as is evident from the list of topics above, no attempt is made to even reflect on the debate about the indigenisation of worship. A further feature of the prescribed study material for this section is that it is designed only by white authors and are prescribed and recommended.

In the module on diaconal service, some attempt is made to attend to the existential needs and situation of the intended recipients of pastoral services. The following topics are dealt with:

- Poverty in South Africa.

- African traditional religions and the promotion of community living in Africa.

- What is diaconal service.

- The Afro-Christian approach to Christian ministry.

- Definition of important concepts, that is diakonia, diakonos, deaconess, deaconate and koinonia.

- Biblical perspectives.

- Theological perspectives.

- Diaconal service in the early church.

- Diaconal service during the Middle Ages.

- Diaconal service during the Reformation.

These and other attempts for the African perspective to feature in the training of ministers, however laudable, are not yet sufficient I for one believe that much more can and should be done to prepare and equip ministers and theologians for meaningful service to black African Christians. The great challenge for the church in Africa lies in the indigenisation of the Christian ministry in order to be of true service to African Christians. Further research that will provide contours for an indigenised ministry for the Hervormde Kerk in Suidelike Afrika is therefore necessary.

\section{CONCLUSION}

This article pointed out that black African Christians are often subjected to incredible suffering because of the activity of evil forces. It was also pointed 
out that this suffering does not correlate with the dominant aspiration of black Africans, namely the aspiration to good health and abundant life. A Christian church that ministers to black Africans therefore cannot serve in the same way it would serve Europeans who view the illness/health situation purely and exclusively in physical and medical terms. I have indicated that there is a lacuna in the ministry of the Hervormde Kerk in Suidelike Afrika with its predominantly black African membership. The necessity for a Christian ministry that takes the African worldview seriously has been proposed as the subject of further research.

\section{Works consulted}

Berinyuu, A A 1988. Pastoral care to the sick in Africa. Frankfurt am Main: Verlag Peter Lang.

De Klerk, J J 1978. Herderkunde. Pretoria: NG Kerkboekhandel.

Dreyer, T F J 1981. Poimeniek: 'n Pastorale orientasie. Pretoria: HAUM.

Ejizu, C I 2002. African traditional religions and the promotion of community:

Dynamics of interreligious encounter: A reader, 59-72. Compiled by M M Karecki. University of South Africa, Pretoria. (Reader for CMM307-3.)

Gerkin, C V 1997. An introduction to pastoral care. Nashville, TN: Abingdon Press.

Haule, C 1969. Bantu "witchcraft" and Christian morality: The encounter of Bantu uchawi with Christian morality: An anthropological and theological study. Immenzee. (Neue Zeitschrift für Missionwissenschaft, Supplementa XVI.)

Hayes, S 1995. Christian responses to witchcraft and sorcery. Missionalia 23(3), 339354.

Jonker, $\mathrm{H}$ 1986. New accents on the healing ministry of the church, in De Villiers, $\mathrm{P}$ G R (ed), Healing in the name of God, 143-151. Pretoria: CB Powell Bible Centre, University of South Africa.

Kgatla, S T 2000. Moloi ga a na mmala (A witch has no colour): A socio-religious study of witchcraft accusations in the Northern Province of South Africa. DLitt et Phil thesis, University of South Africa.

Kramer, J R 1978. Siekepastoraat en die sielkunde van die sieke. BD thesis, University of Pretoria.

Kritzinger, J N J et al 2000. Exploring theology: An introductory dictionary in Engelbrecht, J (ed), compiled by Mary Ralphs. Pretoria: Research Institute for Theology and Religion, University of South Africa.

Maimela, S S 1985. Salvation in African traditional religions. Missionalia, 13(2), 6377.

Mbiti, J S 1970. Concepts of God in Africa. London: SPCK.

Moila, M P 2002. Challenging issues in African Christianity. Pretoria: CB Powell Bible Centre, University of South Africa.

Mwalwa, M 1999. The reality of witchcraft: Pastors must choose between two kingdoms that are mutually exclusive. The Church leader in Africa: A Training Publication of African Ministry Resources 9(2), 6-7. 
Nyirongo, L 1997. The gods of Africa or the God of the Bible? The snares of African traditional religion in Biblical perspective. Potchefstroom: Potchefstroom University for Christian Higher Education.

Parrinder, G (ed) 1971. Traditional Africa, in Man and his gods: Encyclopaedia of the World's Religions, 55-61. London: The Hamlyn Publishing Group.

Ramashapa, J M 1996. Northern Basotho worldview: A theological reflection. NGTT 37(2), 353-359.

Shorter, A 1985. Jesus and the witch doctor: An approach to healing and wholeness. London: Oribis Books.

Stebbing, M L 1985. Concepts of salvation amongst the African Independent Churches in Chipinge, Zimbabwe. MTh dissertation, University of South Africa.

Van Aarde, A G 1987. Demonology in New Testament, in De Villiers, P G R (ed), Like a roaring lion, 22-37. University of South Africa.

Van Biljon, J A 1984. Die siekepastoraat as kerklike bediening in hospitaal-konteks. DD Thesis, Universiteit van Pretoria.

Van Dyk, A C 2001. Traditional African beliefs and customs: Implications for AIDS education and prevention in Africa. South African Journal of Psychology 31(2), 60-66.

Wehmeier, S \& Ashby, M 2000. Oxford Advanced Learner's Dictionary. Sixth Edition. Za'li, L G 1999. Case study: The church and the witch in my village. The Church Leader in Africa: A Training Publication of African Ministry Resources 9(2), 45. 